\title{
Bioactivity of the compounds isolated from Blepharocalyx salicifolius
}

\section{Ezequias P. Siqueira, ${ }^{* 1}$ Djalma M. Oliveira, ${ }^{2}$ Susana Johann, ${ }^{3}$ Patrícia S. Cisalpino, ${ }^{3}$ Betania B. Cota, ${ }^{1}$ Ana Rabello, ${ }^{1}$ Tânia M. A. Alves, ${ }^{1}$ Carlos L. Zani ${ }^{1}$}

${ }^{1}$ Centro de Pesquisa René Rachou, Brazil,

${ }^{2}$ Universidade Estadual do Sudoeste de Bahia, Campus de Jequié, Brazil,

${ }^{3}$ Universidade Federal de Minas Gerais, Instituto de Ciências Biológicas, Brazil.

\begin{abstract}
Blepharocalyx salicifolius (Kunth) O. Berg, Myrtaceae, is an endemic species that occurs at Southern America. This species was studied to intend to isolation of the active compounds that could be used in vitro model against leishmaniosis, tumoral cell and paracoccidioidomycosis. After Gel Permeation Chromatography, the ethanolic extract from leaves yielded sixteen fractions. Five compounds were isolated and assayed, showing activity against tumoral cells, from 3.33 to $12.83 \mu \mathrm{g} \cdot \mathrm{mL}^{-1}$; Leishmania (Leishmania) amazonensis from 2.19 to 20.80 $\mu \mathrm{g} . \mathrm{mL}^{-1}$ and Paracoccidioides brasiliensis from 3.10 to $12.5 \mu \mathrm{g} . \mathrm{mL}^{-1}$.
\end{abstract}

Revista Brasileira de Farmacognosia Brazilian Journal of Pharmacognosy 21(4): 645-651, Jul./Aug. 2011

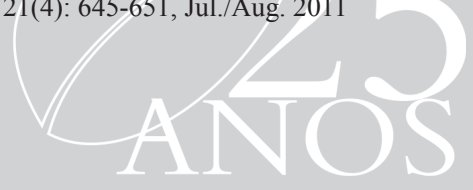

\section{Article}

Received 13 Dec 2010 Accepted 15 Feb 2011 Available online 17 Jun 2011

Keywords: biological assays Blepharocalyx salicifolius chalcone flavonoid Myrtaceae triterpene

ISSN 0102-695X doi: 10.1590/S0102-695X2011005000111

\section{Introduction}

Blepharocalyx salicifolius (Kunth) O. Berg, Myrtaceae, is an endemic species that occurs at Southern America, especially in countries like Brazil, Paraguay, Argentina and Uruguay. It is a bush that grows until $15 \mathrm{~m}$ length. The popular culture has presented several therapeutic indications for this species (Mors et al., 2000). Biological activities, by means of infusion from leaves, have been described as antibacterial (with Staphylococcus aureus and Echerichia coli), anti-inflammatory, antinociceptive, antispasmodic and intestinal transit models (Limberger et al., 2001). Five compounds were isolated and assayed against the pathogenic agents of the leishmaniasis, paracoccidioidomycosis and additionally against human cancer cell lines. It is necessary to improve the therapeutic arsenal against these diseases because the actual drugs are insufficient, very toxic or the parasites have presented resistance (Pecoul et al., 1999). This work is part of the ongoing research project for this species, in order to discover compounds, from natural source, which can be used for this purpose. (Siqueira et al., 2010).

\section{Material and Methods}

General

Gel Permeation Chromatography (GPC) was carried out using Sephadex ${ }^{\mathrm{TM}}$ LH-20 gel (GE Healthcare, USA). Ethanol was used as mobile phase. Thin layer chromatography (TLC) was developed using silica $\mathrm{HF}_{254}$ plates (Merck). The spots were visualized after spraying the plates with vanillin-sulfuric acid or NP/PEG (diphenylborinic acid ethanolamine ester - polyethylene glycol). Adsorptive column chromatography (ACC) was carried out using silica-gel 60-230 mesh (Merck) or Silicagel HF 60 (Merck). Reverse Phase HPLC (RP-HPLC) was carried out by Shimadzu HPLC System, using a Shimpack $^{\circledR} \mathrm{C} 18$ column $(5 \mu \mathrm{m}, 250 \mathrm{~mm}$ x $20 \mathrm{~mm}$ i.d.). Gas Chromatography/Mass Spectrometry (GC/MS) analyses were performed on a Shimadzu QP-5050A instrument, equipped with a with a PTETM-5 column $(30 \mathrm{~m}, 0.25 \mathrm{~mm}$, $0.25 \mu \mathrm{m}$, Supelco, USA), using helium as the carrier gas. Nuclear Magnetic Resonance (NMR) experiments $\left({ }^{1} \mathrm{H}\right.$ and ${ }^{13} \mathrm{C}$, DEPT, HMQC, HMBC and COSY) were recorded on a Brucker DRX 400 spectrometer using standard Bruker pulse sequences and appropriate solvents. Electron impact (70 eV) low-resolution mass spectra (EI-MS) were obtained by means of direct injection on a Shimadzu QP5050A device. 
Crude extract

Leaves of Blepharocalyx salicifolius (Kunth) O. Berg, Myrtaceae, species were collected at Parque Estadual do Rio Preto, Minas Gerais State, Brazil, in November 2006. Exsiccates of the species were committed at UFMG Herbarium (BHCB 87484). Crude extract was obtained by means of maceration of the B. salicifolius leaves. The material was dried using an oven at $35{ }^{\circ} \mathrm{C}$ for two weeks. The leaves were grounded and conditioned in ethanol (analytical grade). Extraction process was performed three times. The raw extract was obtained after filtration and evaporation to dryness, using a rotary evaporator.

\section{Isolation of the compounds}

Raw extract (about $3.74 \mathrm{~g}$ ) was dissolved in ethanol $(20 \mathrm{~mL})$ and injected in the GPC system. It was obtained 190 fractions that were grouped by means of TLC, according to chemical profile, using dichloromethane/methanol $(95 / 5 \mathrm{v} / \mathrm{v})$ as eluent and revealed with vanillin/sulfuric acid to give sixteen new fractions named F1 to F16.

The compounds $\mathbf{1}$ and $\mathbf{2}$ were obtained from F11 and $\mathrm{F} 12$ junction $(373 \mathrm{mg}$ ) and dissolved in $\mathrm{n}$-hexane (10 mL). It was subjected to ACC using a gradient, ranging from $n$-hexane (100\%) to ethyl acetate (100\%). The fractions were collected, yielding 1 (193 $\mathrm{mg})$ and 2 (6.0 mg).

The compounds $3(7 \mathrm{mg})$ and $4(18 \mathrm{mg})$ were obtained from F16 fraction by means of preparative RPHPLC methodology. The material from F16 fraction (150 mg) was dissolved in $10 \mathrm{~mL}$ methanol/water $(1 / 1$ $\mathrm{v} / \mathrm{v}$ ) and purified by RP-HPLC, using methanol/water gradient as eluent.

The F5 fraction (200 $\mathrm{mg}$ ) was partitioned between methanol and $n$-hexane three times. The methanolic phase was partitioned sequentially, using a mixture of $n$-hexane/ethyl acetate $(70 / 30 \mathrm{v} / \mathrm{v})$, until complete exhaustion of methanolic phase. After evaporation of the solvent, this material was purified by ACC, using isocratic hexane/ethyl acetate $(70 / 30 \mathrm{v} / \mathrm{v})$ as eluent. The fractions were collected and analyzed by TLC, yielding compound 5 (17 mg).

Compound 1: ${ }^{1} \mathrm{H}$ NMR (400 MHz, $\mathrm{CDCl}_{3}$ ) $\delta 13.63$ (s, $1 \mathrm{H}), 7.98(\mathrm{~d}, 1 \mathrm{H}, J=16.0 \mathrm{~Hz}), 7.83(\mathrm{~d}, 1 \mathrm{H}, J=16.0$ $\mathrm{Hz}), 7.64-7.61(\mathrm{~m}, 2 \mathrm{H}), 7.42-7.37(\mathrm{~m}, 3 \mathrm{H}), 5.70(\mathrm{~s}$, 1H), 3.65 (s, 3H), $2.15(\mathrm{~s}, 3 \mathrm{H}), 2.13(\mathrm{~s}, 3 \mathrm{H}) .{ }^{13} \mathrm{C}$ NMR $\left(100 \mathrm{MHz} \mathrm{CDCl}_{3}\right) \oint 193.4,162.0,159.4,158.8,142.9$, $135.3,130.2,128.9,128.4,126.7,109.0,109.1,106.7$, 62.3, 8.2, 7.5. MS/EI $\left(\mathrm{M}^{+}\right) 298$.

Compound 2: ${ }^{1} \mathrm{H}$ NMR (400 MHz, $\mathrm{CDCl}_{3}$ ) $\delta 13.09$ (s,
1H), $7.97(\mathrm{~d}, 1 \mathrm{H}, J=16.0 \mathrm{~Hz}), 7.86(\mathrm{~d}, 1 \mathrm{H}, J=16.0$ $\mathrm{Hz})$, 7.66-7.63 (m, 2H), 7.42-7.39 (m, 3H), 3.75 (s, $3 \mathrm{H}), 3.66(\mathrm{~s}, 3 \mathrm{H}), 2.17(\mathrm{~s}, 3 \mathrm{H}), 2.16(\mathrm{~s}, 3 \mathrm{H}) .{ }^{13} \mathrm{C} \mathrm{NMR}$ $\left(100 \mathrm{MHz} \mathrm{CDCl}_{3}\right) \delta .194 .1,163.7,161.7,158.7,143.4$, $135.3,130.4,128.9,128.5,126.6,115.7,115.6,111.9$, 62.3, 60.1, 8.8, 8.7. MS/EI $\left(\mathrm{M}^{+}\right) 312$.

Compound 3: ${ }^{1} \mathrm{H}$ NMR (400 MHz, $\mathrm{CD}_{3} \mathrm{OD}$ ) $\delta$ 7.37-7.32 $(\mathrm{m}, 2 \mathrm{H}), 6.94(\mathrm{~d}, 1 \mathrm{H}, J=8.0 \mathrm{~Hz}), 6.40(\mathrm{~d}, 1 \mathrm{H}, J=2.0$ $\mathrm{Hz}), 6.23(\mathrm{~d}, 1 \mathrm{H}, J=2.0 \mathrm{~Hz}), 5.38(\mathrm{~d}, 1 \mathrm{H}, J=1.6 \mathrm{~Hz})$, $4.30(\mathrm{dd}, 1 \mathrm{H}, J=3.3$ and $1.6 \mathrm{~Hz}), 3.78(\mathrm{dd}, 1 \mathrm{H}, J=$ 9.0 and $3.3 \mathrm{~Hz}), 3.45-3.37(\mathrm{~m}, 2 \mathrm{H}), 0.97(\mathrm{~d}, 3 \mathrm{H}, J=$ $6.0 \mathrm{~Hz}) .{ }^{13} \mathrm{C}$ NMR (100 MHz, CD $\left.\mathrm{OD}\right) \delta 179.8,166.0$, $163.4,159.5,158.7,150.0,146.6,136.4,123.1,123.0$, $117.1,116.5,103.7,100.0,94.8,73.4,72.3,72.2,72.0$, 17.8. MS/EI $\left(\mathrm{M}^{+}\right) 448$.

Compound 4: ${ }^{1} \mathrm{H}$ NMR (400 MHz, CD 3 OD) $\delta$ 7.49-7.44 $(\mathrm{m}, 2 \mathrm{H}), 6.86(\mathrm{~d}, 1 \mathrm{H}, J=8.0 \mathrm{~Hz}), 6.36(\mathrm{~d}, 1 \mathrm{H}, J=2.0$ $\mathrm{Hz}), 6.17$ (d, 1H, J=2.8 Hz), 5.43 (bs, 1H), 4.29 (dd, $1 \mathrm{H}, J=2.8$ and $1.0 \mathrm{~Hz}), 3.85-3.75(\mathrm{~m}, 2 \mathrm{H}), 3.41-3.38$ $(\mathrm{m}, 2 \mathrm{H}) .{ }^{13} \mathrm{C}$ NMR $\left(100 \mathrm{MHz}, \mathrm{CD}_{3} \mathrm{OD}\right) \delta 180.2,166.2$, $163.3,159.5,158.7,150.0,146.5,135.1,123.3,123.2$, 117.0, 116.6, 109.7, 100.0, 94.9, 88.2, 83.5, 78.9, 62.7. $\mathrm{MS} / \mathrm{EI}\left(\mathrm{M}^{+}\right) 434$.

Compound 5: ${ }^{1} \mathrm{H}$ NMR (400 MHz, CD $\left.\mathrm{OD}\right) \delta 5.23(\mathrm{~s}$, $1 \mathrm{H}), 3.21(\mathrm{dd}, 1 \mathrm{H}, J=9.5$ and $5.2 \mathrm{~Hz}) ; 2.28(\mathrm{~d}, 1 \mathrm{H}, J$ $=11.1 \mathrm{~Hz}), 1.98(\mathrm{dd}, 2 \mathrm{H}, J=13.7$ and $3.5 \mathrm{~Hz}), 1.64$ $(\mathrm{m}, 2 \mathrm{H}) ; 1.63(\mathrm{~s}, 1 \mathrm{H}) ; 1.61(\mathrm{~m}, 2 \mathrm{H}) ; 1.60(\mathrm{~m}, 2 \mathrm{H}), 1.57$ $(\mathrm{m}, 1 \mathrm{H}), 1.51(\mathrm{~m}, 1 \mathrm{H}), 1.48(\mathrm{~m}, 2 \mathrm{H}), 1.36(\mathrm{~m}, 1 \mathrm{H}), 1.35$ $(\mathrm{m}, 1 \mathrm{H}), 1.34(\mathrm{~m}, 2 \mathrm{H}), 1.31(\mathrm{~m}, 2 \mathrm{H}), 1.10(\mathrm{~s}, 3 \mathrm{H}), 1.09$ $(\mathrm{m}, 2 \mathrm{H}), 0.95(\mathrm{~d}, 3 \mathrm{H}, J=6.8 \mathrm{~Hz}), 0.93(\mathrm{~s}, 3 \mathrm{H}), 0.89$ (s, $3 \mathrm{H}), 0.85(\mathrm{~d}, 3 \mathrm{H}, J=5.9 \mathrm{~Hz}) ; 0.71(\mathrm{~s}, 3 \mathrm{H}), 0.70(\mathrm{~s}, 3 \mathrm{H})$, $0.69(\mathrm{~s}, 1 \mathrm{H}) .{ }^{13} \mathrm{C}-\mathrm{NMR}\left(100 \mathrm{MHz}, \mathrm{CD}_{3} \mathrm{OD}\right): \delta 179.0$, $138.3,124.9,78.3,77.2,55.1,52.7,47.4,41.8,39.2$, $38.9,38.7,38.6,38.5,36.7,36.7,32.8,30.6,29.4,28.0$, 28.1, 27.0, 24.2, 23.3, 23.0, 21.0, 18.1, 16.8, 16.7, 15.5, 15.1. MS/EI $\left(\mathrm{M}^{+}\right) 456$.

\section{Biological Assays}

lineages

Cytotoxicity assays with human cancer cell

The cytotoxicity assays were performed using the tumor cell lineages UACC-62 (human melanoma), MCF-7 (human breast cancer) and TK-10 (human renal cancer). The cell lineages were purchased from the National Cancer Institute (NCI, Maryland, USA). The cell toxicity assays were run according to the protocols established at NCI, using the sulphorhodamine colorimetric assay (Monks et al., 1991). Results were expressed in terms of the growth inhibition percentage $(\%)$, where the sample tested was considered cytostatic 
from $0-99 \%$ and cytocidal from $100-200 \%$.

Assays using amastigotes-like of Leishmania (Leishmania) amazonensis

Promastigotes of L. (L.) amazonensis (strain IFLA/BR/196/PH-8) were obtained from lesions of infected hamsters. The assays were run according to Teixeira et al. (2002). The results were expressed as percent of inhibition in relation to the controls without drug.

Culture and maintenance of Paracoccidioides brasiliensis

Eleven clinical $P$. brasiliensis strains, $\mathrm{Pb}-01$ (ATCC- MYA-826), Pb-18 (Fungi Collection of the Faculty of Medicine of the Universidade de São Paulo, São Paulo, SP, Brazil), Pb-B339 (ATCC 32069), Pb-14 (clinical isolate from acute PCM, São Paulo, Brazil), $\mathrm{Pb}-3$ and $\mathrm{Pb}-4$ (clinical isolates from chronic PCM, São Paulo, Brazil-MHH Forjaz/TIE Svidzinski), Pb-2 (Epm 60 ), $\mathrm{Pb}-1578, \mathrm{~Pb}-\mathrm{ED} 01, \mathrm{~Pb}-11, \mathrm{~Pb}-8$ (clinical isolates from acute PCM, Paraná, Brazil, TIE Svidzinski) were used in the biological assays. P. brasiliensis strains were maintained according to the CLSI document $\mathrm{M}$ 27-A2 (NCCLS, 2002).

Determination of the Minimal Inhibitory Concentrations (MIC)

Susceptibility was determined by the microbroth dilution method. Broth microdilution test was performed in accordance with the guidelines in the CLSI M27-A, document (NCCLS, 2002) and modifications suggested by Johann et al. (2010).

Determination of the Minimal Fungicidal Concentrations (MFC)

The MFC values for pure compounds were determined according to Espinel-Ingroff et al. (2001) and Portillo et al. (2005).

\section{Results and Discussion}

\section{Isolated compounds}

The structures of the compounds were established by their 1D and 2D NMR spectroscopic data and comparison with literature data. The compound 1 was identified as (2E)-1-(2',4'-dihydroxy-6'methoxy-3',5'-dimethylphenyl)-3-phenylprop-2-en1 -one, a chalcone isolated in other species (Malterud et al., 1977; Gonzales et al., 1992; Gafner et al.,
1996). The compound 2, (2E)-1-(4'-hydroxy-2',6'dimethoxy-3',5'-dimethylphenyl)-3-phenylprop-2-en1-one, showed similar structure to $\mathbf{1}$, seems to be an unedited substance. The compounds 3-4, isolated as pale yellow solids, were elucidated by means of NMR data, hydrolysis, peracetylation and GC/MS analysis (Cota et al., 2008; Monteiro et al.,2009; Monteiro et al., 2010). It was possible to confirm the identity of the sugar moiety as rhamnose for 3 (Figure 1) and arabinose for 4 (Figure 2). Pure quercitrin, purchased from Sigma-Aldrich, has corroborated our elucidation for 3. This flavonoid is a usual substance, isolated from several species (Hallet \& Parks 1951; Lopez, 1982; Kato et al., 2010). The compound 4 had similar aglyconic molecular structure to $\mathbf{3}$ thus, the substance was elucidated as guaijaverin, a flavonoid found in several species (Mair et. al., 1987; Arisawa et al, 1993; $\mathrm{Xu}$ et al., 2009). By means of spectroscopic data and literature (Seebacher et al, 2003; Silva et al, 2008), it was possible to confirm the identity of the $\mathbf{5}$ as ursolic acid, (3ß-hydroxy-urs-12-en-28-oic acid), an ursanic triterpene isolated from several species (Fu et al., 2005; Leite et al., 2006; Cunha et al., 2007).

These five compounds are reported herein for the first time for this genus and species. Previous report about this genus has described GC-MS analysis of the essential oils, where the principal identified compounds were monoterpenes and sesquiterpenes (Limberger et al., 2001).<smiles>Cc1c(C)c(O)c(C(=O)/C=C/c2ccccc2)c(O)c1C</smiles><smiles>COc1c(C)c(O)c(C)c(O)c1C(=O)/C=C/c1ccccc1</smiles>

2<smiles>[R]OC1=C(c2ccc(O)c(O)c2)Cc2cc(O)cc(O)c2C1=O</smiles><smiles>CC1C2C3=CCC4C5(C)CC[C@H](O)C(C)(C)C5CC[C@@]4(C)[C@H]3CCC2(C(=O)O)CC[C@@H]1C</smiles>

$3 \mathrm{R}=$ rhamnose $4 R=$ arabinose

\section{Biological assays}

All compounds were evaluated against three human tumor cell lineages: UACC-62 (melanoma), MCF-7 (breast cancer) and TK-10 (renal cancer), against amastigotes-like of $L$. (L.) amazonensis and $P$. brasiliensis. The results, (Table 1), demonstrated that only chalcones (1-2) had activity for all biological assays. They exhibited antifungal activity against all 


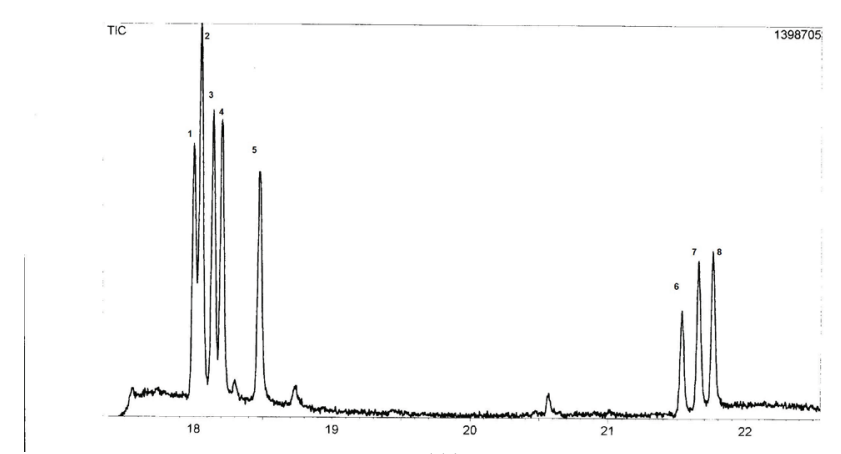

(A)

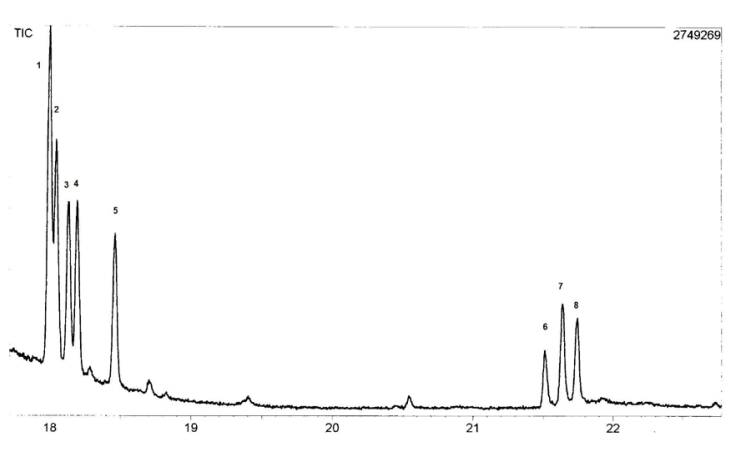

(B)

Figure 2. Profile of sugars standards A: 1, rhamnose; 2, ribose; 3, fucose; 4; arabinose; 5, xylose; 6, mannose; 7, glucose, and 8, galactose. Sugar standards plus sample from hydrolysis of 3, showing an increase in rhamnose (B).

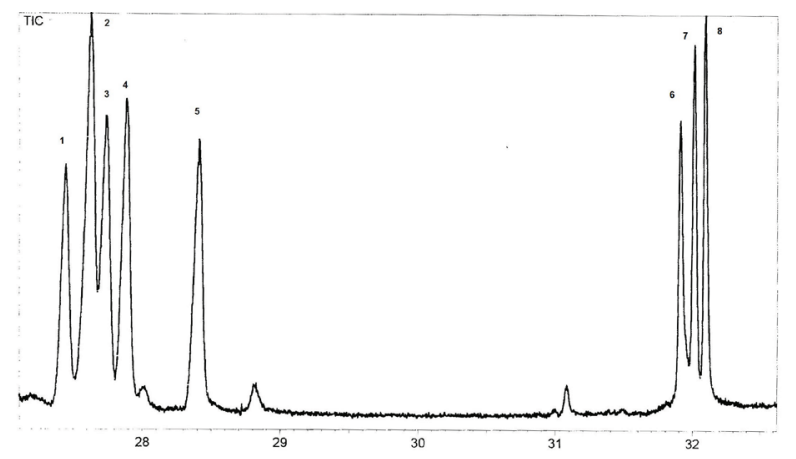

(A)

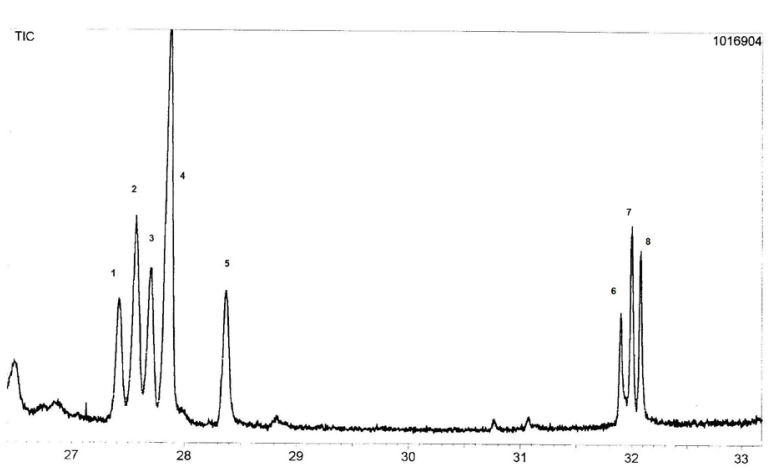

(B)

Figure 3. Profile of sugars standards A: 1, rhamnose; 2, ribose; 3, fucose; 4; arabinose; 5, xylose; 6, mannose; 7, glucose, and 8, galactose. Sugar standards plus sample from hydrolysis of 4 , showing an increase in arabinose (B).

isolates of $P$. brasiliensis, with MIC values ranging from 3.1 to $12.5 \mu \mathrm{g} . \mathrm{mL}^{-1}$. The results for MFC activity for 1 were two concentration orders above MIC results for $\mathrm{Pb}-18$ and $\mathrm{Pb}-\mathrm{B} 339$ (3.1 and $12.5 \mu \mathrm{g} \cdot \mathrm{mL}^{-1}$, for both strains, respectively). Compound $\mathbf{2}$ demonstrated MFC results one concentration order above MIC for $\mathrm{Pb}-18, \mathrm{~Pb}-\mathrm{B} 339, \mathrm{~Pb}-01$ and $\mathrm{Pb}-1578$ strains (3.1 and $6.2 \mu \mathrm{g} . \mathrm{mL}^{-1}$, for all strains, respectively). Although antifungal activity has been related to chalcones, this is the first work that describes fungicide activity for these compounds against $P$. brasiliensis. Chalcones $\mathbf{1}$ and 2 exhibited the best IC50 values against amastigoteslike of L. (L.) amazonensis between the five isolated compounds (5.23 and $2.19 \mu \mathrm{g} . \mathrm{mL}^{-1}$, respectively). Torre-Santos et al. (1999) showed an IC50 of $24 \mu \mathrm{g} \cdot \mathrm{mL}^{-1}$ against intracellular amastigotes of $L$. (L.) amazonensis for structurally similar chalcone, 2',6'-dihydroxy4'-methoxychalcone, isolated from dichloromethane extract of Piper aduncum inflorescences.

Chalcones $\mathbf{1}$ and $\mathbf{2}$ were active against all cancer cell lineages tested. They presented values of IC50 ranging from 3.00 to $10.83 \mu \mathrm{g} . \mathrm{mL}^{-1}$ and MCF-7 lineage was the most sensitive to these compounds. The literature reports scarce biological activity for chalcone 1. It was noticed antimicrobial activity against Staphylococcus aureus (MIC of $250 \mu \mathrm{g} . \mathrm{mL}-1$ ) (Belofsky et al., 2004) and Mycobacterium tuberculosis (MIC of $62.5 \mu \mathrm{g} . \mathrm{mL}^{-1}$ ) (Pavan et al., 2009) and it was not reported any biological activity for chalcone 2 .

Quercitrin (3) and guaijaverin (4) exhibited only leishmanicidal activity, with IC50 values of 6.25 and 20.80 $\mu \mathrm{g} . \mathrm{mL}^{-1}$, respectively. The kind of sugar linked to aglycone moiety on flavonoids affects its activity. According to Muzitano et al. (2006) quercitrin, isolated from aqueous leaf's extract from Kalanchoe pinnata, had an IC50 of 8 $\mu \mathrm{g} . \mathrm{mL}^{-1}$ and the presence of quercetin aglycone and the sugars linked to, suggests the importance of this structural feature for antileishmanial activity. Aglycon quercetin, together with five of its glycosides, which includes quercitrin and guaijaverin, were isolated from Psidium guajava L. This species is used against diarrhea and the results demonstrated that the ability to inhibit peristalsis is mainly due to the aglycon quercetin (Lozoya et al., 1994).

Ursolic acid is a ubiquitous pentacyclic triterpenoid in plant kingdom (Liu, 2005). Our results demonstrated that this compound was had cytotoxic against all cell lineages tested (IC50 ranging from 10.83 to $\left.12.83 \mu \mathrm{g} \cdot \mathrm{mL}^{-1}\right)$. This compound has showed 
Table 1. Results of the biological assays expressed in concentration of the compound $\left(\mu \mathrm{g} \cdot \mathrm{mL}^{-1}\right)$ sufficient to inhibit the growth or to kill the pathogenic agents.

\begin{tabular}{|c|c|c|c|c|c|c|}
\hline \multirow{2}{*}{ Pathogenic agent } & \multicolumn{6}{|c|}{ Compounds } \\
\hline & 1 & 2 & 3 & 4 & 5 & Control \\
\hline TK-10 & $4.33 \pm 0.58$ & $10.83 \pm 1.44$ & Not active & Not active & $12.83 \pm 3.01$ & $16^{\mathrm{d}}$ \\
\hline $\mathrm{UACC}^{\mathrm{a}}$ & $5.00 \pm 0.10$ & $7.00 \pm 1.73$ & Not active & Not active & $10.83 \pm 1.44$ & $16^{\mathrm{e}}$ \\
\hline$M C F-7^{a}$ & $3.33 \pm 0.57$ & $3.00 \pm 1.80$ & Not active & Not active & $11.67 \pm 1.44$ & $16^{\mathrm{f}}$ \\
\hline L.(L.) amazonensis ${ }^{\mathrm{b}}$ & $5.23 \pm 1.84$ & $2.19 \pm 1.60$ & $6.25 \pm 0.10$ & $20.80 \pm 7.21$ & $9.34 \pm 6.80$ & $0.20^{\mathrm{g}}$ \\
\hline $\mathrm{Pb}-01^{\mathrm{c}}$ & $6.20 / 6.20$ & $3.10 / 6.20$ & $\geq 200 / \geq 200$ & $\geq 200 / \geq 200$ & $\geq 200 / \geq 200$ & $300 / 300$ \\
\hline $\mathrm{Pb}-18^{\mathrm{c}}$ & $3.10 / 12.50$ & $3.10 / 6.20$ & $\geq 200 / \geq 200$ & $\geq 200 / \geq 200$ & $\geq 200 / \geq 200$ & $300 / 300$ \\
\hline $\mathrm{Pb}-\mathrm{B} 339^{\mathrm{c}}$ & $3.100 / 12.50$ & $3.10 / 6.20$ & $\geq 200 / \geq 200$ & $\geq 200 / \geq 200$ & $\geq 200 / \geq 200$ & $75 / 75$ \\
\hline $\mathrm{Pb}-14^{\mathrm{c}}$ & $6.20 / 6.20$ & $6.20 / 6.20$ & $\geq 200 / \geq 200$ & $\geq 200 / \geq 200$ & $\geq 200 / \geq 200$ & $75 / 75$ \\
\hline $\mathrm{Pb}-3^{\mathrm{c}}$ & $6.20 / 6.20$ & $6.20 / 6.20$ & $\geq 200 / \geq 200$ & $\geq 200 / \geq 200$ & $\geq 200 / \geq 200$ & $300 / 300$ \\
\hline $\mathrm{Pb}-4^{\mathrm{c}}$ & $12.50 / 12.50$ & $12.50 / 12.50$ & $\geq 200 / \geq 200$ & $\geq 200 / \geq 200$ & $\geq 200 / \geq 200$ & $150 / 150$ \\
\hline $\mathrm{Pb}-2^{\mathrm{c}}$ & $6.20 / 6.20$ & $6.20 / 6.20$ & $\geq 200 / \geq 200$ & $\geq 200 / \geq 200$ & $\geq 200 / \geq 200$ & $150 / 150$ \\
\hline $\mathrm{Pb}-1578^{\mathrm{c}}$ & $3.10 / 3.10$ & $3.10 / 6.20$ & $\geq 200 / \geq 200$ & $\geq 200 / \geq 200$ & $\geq 200 / \geq 200$ & $75 / 75$ \\
\hline $\mathrm{Pb}-\mathrm{ED} 01^{\mathrm{c}}$ & $6.20 / 6.20$ & $6.20 / 6.20$ & $\geq 200 / \geq 200$ & $\geq 200 / \geq 200$ & $\geq 200 / \geq 200$ & $75 / 75$ \\
\hline $\mathrm{Pb}-11^{\mathrm{c}}$ & $6.20 / 6.20$ & $6.20 / 6.20$ & $\geq 200 / \geq 200$ & $\geq 200 / \geq 200$ & $\geq 200 / \geq 200$ & $150 / 150$ \\
\hline $\mathrm{Pb}-8^{\mathrm{c}}$ & $6.20 / 6.20$ & $6.20 / 6.20$ & $\geq 200 / \geq 200$ & $\geq 200 / \geq 200$ & $\geq 200 / \geq 200$ & $300 / 300$ \\
\hline
\end{tabular}

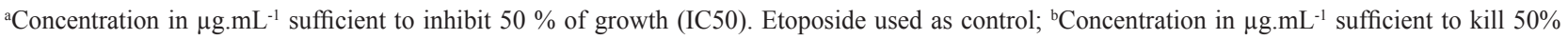
of the population of cells (LC50). Amphotericin B used as control; ${ }^{\circ}$ Concentration in $\mu \mathrm{g} \cdot \mathrm{mL}^{-1}$ sufficient to inhibit the growth (first data)/to kill the culture (second data). Sulfametoxazol-trimetoprim used as control; ${ }^{\mathrm{d} C o n c e n t r a t i o n ~ i n ~} \mu \mathrm{g} \cdot \mathrm{mL}^{-1}$ sufficient to inhibit $72 \%$ of growth of TK-10 strain; ${ }^{\mathrm{e}}$ Concentration in $\mu \mathrm{g} \cdot \mathrm{mL}^{-1}$ sufficient to inhibit $94 \%$ of growth of UACC strain; ${ }^{\mathrm{f}}$ Concentration in $\mu \mathrm{g} \cdot \mathrm{mL}^{-1}$ sufficient to inhibit $79 \%$ of growth of MCF-7 strain; ${ }^{g}$ Concentration in $\mu \mathrm{g} \cdot \mathrm{mL}^{-1}$ sufficient to kill $66 \%$ of the populations of cells.

significant cytotoxicity against several tumor cell lines as HL-60, K562, M4Beu, and HSC-2, with IC50 values ranging from 5.0 to $29.0 \mu \mathrm{g} . \mathrm{mL}^{-1}$ (Vechia et al., 2009). It is interesting to note that this triterpenoid exhibited IC50 values of $7.0 \mu \mathrm{g} \cdot \mathrm{mL}^{-1}$ and $21 \mu \mathrm{g} \cdot \mathrm{mL}^{-1}$ against Leishmania donovani (da Silva Filho et al., 2009) and Leishmania major (Takahashi et al., 2004), respectively. In our results it demonstrated IC50 value of $9.34 \mu \mathrm{g} . \mathrm{mL}^{-1}$ against L. (L.) amazonensis.

\section{Conclusions}

It was isolated five compounds where the chalcone 2 seems be a new one. Although the other four compounds are usual, it was the first time that they were isolated in this genus and species. The chalcones $\mathbf{1}$ and $\mathbf{2}$ showed be active against all biological models researched moreover it was the first time that these compounds ( $\mathbf{1}$ and $\mathbf{2}$ ) were tested on these biological assays. Thus, these two chalcones are promising structures to the development of new drugs, showing the pharmacological potential of the Blepharocalyx salicifolius, a species little studied.

\section{Acknowledgements}

The authors thank CNPq-FIOCRUZ PAPES Program and FAPEMIG for all financial support.

\section{References}

Arisawa M, Horiuchi T, Hayashi T, Tezuka Y, Kikuchi T, Morita N 1993. Studies on constituents of Evodia rutaecarpa (Rutaceae). I. Constituents of the leaves. Chem Pharm Bull 41: 1472-1474.

Belofsky G, Percivill D, Lewis K, Tegos GP, Ekart J 2004. Phenolic metabolites of Dalea versicolor that enhance antibiotic activity against model pathogenic bacteria. $J$ Nat Prod 67: 481-484.

Cota BB, Magalhães A, Pimenta AMC, Siqueira EP, Alves TMA, Zani CL 2008. Chemical constituents of Habenaria petalodes Lindl. (Orchidaceae). J Braz Chem Soc 19: 1098-1104.

Cunha LCS, Andrade SML, Furtado NAJC, Vinholis AHC, Martins CHG, Silva FAA, Cunha WR 2007. Antibacterial activity of triterpene acids and semisynthetic derivatives against oral pathogens. $J$ Biosciences 62: 668-672.

da Silva Filho AA, Resende DO, Fukui MJ, Santos FF, Pauletti PM, Cunha WR, Silva MLA, Gregorio LE, Bastos JK, Nanayakkara NPD 2009. In vitro antileishmanial, antiplasmodial and cytotoxic activities of phenolics and triterpenoids from Baccharis dracunculifolia D. C. (Asteraceae). Fitoterapia 80: 478-482.

Espinel-Ingroff A, Boyle K, Sheehan DJ 2001. In vitro antifungal activities of voriconazole and reference agents as determined by NCCLS methods: review of 
the literature. Mycopathologia 150: 101-115.

Fu L, Zhang S, Li N, Wang J, Zhao M, Sakai J, Hasegawa T, Mitsui T, Kataoka T, Oka S, Kiuchi M, Hirose K, Ando M 2005. Three new triterpenes from Nerium oleander and biological activity of the isolated compounds. $J$ Nat Prod 68: 198-206.

Gafner S, Wolfender JL, Mavi S, Hostettmann K 1996. Antifungal and antibacterial chalcones from Myrica serrata. Planta Med 62: 67-69.

Gonzalez AG, Aguiar ZE, Luis JG, Rivera A, Calle J, Gallo G 1992. A C-methyl chalcone from Dalea caerullea. Phytochemistry 31: 2565-2566.

Hallett FP, Parks LM 1951. A note on the isolation of quercitrin from Euphorbia pilulifera. J Am Pharm Assoc 40: 56-57.

Johann S, Cisalpino PS, Watanabe GA, Cota BB, Siqueira EP, Pizzolatti MG, Zani CL, Resende M A 2010. Antifungal activity of extracts of some plants used in Brazilian traditional medicine against the pathogenic fungus. Pharm Biol 48: 388-396.

Kato H, Li W, Koike M, Wang Y, Koike K 2010. Phenolic glycosides from Agrimonia pilosa. Phytochemistry 71: 1925-1929.

Leite JPV, Oliveira AB, Lombardi JA, Filho JDS, Chiari E 2006. Trypanocidal activity of triterpenes from Arrabidaea triplinervia and derivatives. Bio Phar Bull 29: 2307-2309.

Limberger RP, Sobral MEG, Zuanazzi JAS, Moreno PRH, Schapoval EES, Henriques AT 2001. Biological activities and essential oil composition of leaves of Blepharocalyx salicifolius. Pharm Biol 39: 308-311.

Liu, J 2005. Oleanolic acid and ursolic acid: Research perspectives. J Ethnopharmacol 100: 92-94.

Lopez JA 1982. Isolation of quercitrin from the leaves of Anacardium rhinocarpus D.C., A. excelsum (Bert and Balb.) (Anacardiaceae). Ingen Cienc Quim 6: 148149.

Lozoya X, Meckes M, Abou-Zaid M, Tortoriello J, Nozzolillo C, Arnason JT 1994. Quercetin glycosides in Psidium guajava L. leaves and determination of a spasmolytic principle. Arch Med Res 25: 11-15.

Mair AGR, Pandiyan M, Venkatasubramanian H 1987. Polyphenolic compounds from flowers of Psidium guajava. Fitoterapia 58: 204-205.

Malterud KE, Anthonsen T, Lorentzen GB 1977. Chemistry of Myrica gale L. Part 4. Two new C-methylated flavonoids from Myrica gale. Phytochemistry 16: 1805-1809.

Monks A, Scudiero D, Skehan P, Shoemaker R, Paull K, Vistica D, Hose C, Langley J, Cronise P, Vaigro-Wolff A, Gray-Goodrich M, Campbell H, Mayo J, Boyd M 1991. Feasibility of a high-flux anticancer drug screen using a diverse panel of cultured human tumor cell lines. J Natl Cancer Inst 83: 757-766.

Monteiro AS, Coutinho JOPA, Júnior AC, Rosa CA, Siqueira
EP, Santos VL 2009. Characterization of new biosurfactant produced by CLOA 72 isolated from dairy industry effluents. J Basic Microb 49: 553-563.

Monteiro AS, Bonfim MRQ, Domingues VS, Corrêa JA, Siqueira EP, Zani CL, Santos VL 2010. Identification and characterization of bioemulsifier-producing yeasts isolated from effluents of a dairy industry. Bioresource Technol 101: 5186-5193.

Mors WB, Rizzini CT, Pereira NA 2000. Medicinal Plants of Brazil. 1 ed. Michigan: Reference Publications, p. 501.

Muzitano MF, Tinoco LW, Guette C, Kaiser CR, RossiBergmann B, Costa SS 2006. The antileishmanial activity assessment of unusual flavonoids from Kalanchoe pinnata. Phytochemistry 67: 2071-2077.

National Committee for Clinical Laboratory Standards 2002. M27-A2. Method for broth dilution antifungal susceptibility testing of yeast. 2 ed. Wayne: NCCLS.

Pavan FR, Leite CQF, Coelho RG, Coutinho ID, Honda NK, Cardoso CAL, Vilegas W, Leite SRA, Sato DN 2009. Evaluation of anti-mycobacterium tuberculosis activity of Campomanesia adamantium (Myrtaceae). Quim nova 32: 1222-1226.

Pecoul B, Chirac P, Trouiller P, Pinel J 1999. Access to essential drugs in poor countries - a lost battle? $\mathrm{J} \mathrm{Am}$ Med Ass 281: 361-367.

Portillo A, Vila R, Freixa B, Ferro E, Parella T, Casanova J, Canigueral S 2005. Antifungal sesquiterpene from the root of Vernonanthura tweedieana. J Ethnopharmacol 97: 49-52.

Seebacher W, Simic N, Weis R, Saf R, Kunert O 2003. Complete assignments of ${ }^{1} \mathrm{H}$ and ${ }^{13} \mathrm{C}$ NMR resonances of oleanolic acid, 18a-oleanolic acid, ursolic acid and their 11-oxo derivatives. Magn Reson Chem 41: 636638.

Silva MGV, Vieira IGP, Mendes FNP, Albuquerque IL, Santos RN, Silva FO, Morais SM 2008. Variation of ursolic acid content in eight Ocimum species from northeastern Brazil. Molecules 13: 2482-2487.

Siqueira EP, Fagundes EMS, Sobral MEG, Alves TMA, Rabello A, Zani CL 2010. Leishmanicidal activities of the extract from Blepharocalyx salicifolius (Kunth) O. Berg, Myrtaceae. Rev Bras Farmacogn 20: 416421.

Takahashi M, Fuchino H, Sekita S, Satake M 2004. In vitro leishmanicidal activity of some scarce natural products. Phytother Res 18: 573-578.

Teixeira MC, Santos RJ, Sampaio RB, Carvalho LLP, Santos WL 2002. A simple and reproducible method to obtain large numbers of axenic amastigotes of different Leishmania species. Parasitol Res 88: 963-968.

Torres-Santos EC, Moreira DL, Kaplan MA, Meirelles MN, Rossi-Bergmann B 1999. Selective effect of 2',6'dihydroxy-4'-methoxychalcone isolated from Piper aduncum on Leishmania amazonensis. Antimicrob 
Agents Ch 43: 1234-1241.

Vechia LD, Gnoatto SCB, Gosmann G 2009. Derivados oleananos e ursanos e sua importância na descoberta de novos fármacos com atividade antitumoral, antiinflamatória e antioxidante. Quim Nova 32: 1245 1252.

Xu F, Matsuda H, Hata H, Sugawara K, Nakamura S, Yoshikawa M 2009. Structures of new flavonoids and benzofuran-type stilbene and degranulation inhibitors of rat basophilic leukemia cells from the Brazilian herbal medicine Cissus sicyoides. Chem Pharm Bull 57: 1089-1095.

\section{*Correspondence}

Ezequias P. Siqueira

Centro de Pesquisa René Rachou

Av. Augusto de Lima, 1715, 30190-002 Belo Horizonte, MG, Brazil

ezequias@cpqrr.fiocruz.br

Tel.: +553133497845

Fax: +553132953115 